\title{
Udvikling af national identitet i Island
}

\section{Gudmundur Hálfdanarson}

\section{Islandske politikere fortsætter med at læse landets historie igennem nationalismens briller, hvor nuti- den - uanset hvor forskellig den er fra fortiden - bliver set som en naturlig konsekvens af sagaernes store fortællinger}

Den 21. april 1971 var uden tvivl en af de mest mindeværdige dage i det 20. århundredes Islands historie. En kølig solskinsmorgen sejlede det danske inspektionsskib Vædderen i overværelse af en tusindtalling skare ind i Reykjaviks havn. Med sig bragte skibet to af de største juveler i islandsk middelalderkultur, manuskripterne Codex Regius og Flateyjarbók (Flatø-bogen), som skulle gives tilbage til Island efter lange og opslidende forhandlinger mellem danske og islandske myndigheder.

Alle grundskoler i Island var lukket for dagen for at give den islandske ungdom mulighed for at opleve dette historiske øjeblik, enten personligt eller ved at se det hjemme i den første livetransmitterede udsendelse i islandsk fjernsyn.
Den ceremonielle overdragelse af manuskripterne fandt sted om eftermiddagen samme dag i en af Islands største forsamlingssale, Universitetsbiografen i Reykjavik, hvor den danske kulturminister, Helge Larsen, præsenterede de to bind til sin islandske kollega, Gylfi Gíslason: "Værsågod, Flatøbogen og ældre Edda", bemærkede den danske minister med et lunt glimt i øjet, da han overgav manuskripterne i Gislasons hænder og dermed satte punktum for en lang og ofte forbitret diskussion om ejerskabet til disse to litterære skatte.

For de fleste af de tusindvis af islændinge, som overværede disse begivenheder, var dette en passende afslutning på den islandske kamp for uafhængighed. 
For det første må det have været en stor tilfredsstillelse for dem, som havde kæmpet for at få manuskripterne udleveret fra Danmark, at se den danske flåde bringe skattene tilbage til Island. For dem var dette en oprejsning for, hvad der længe var blevet betragtet som en af de mest ydmygende begivenheder i islandsk historie - dengang da den danske konge udsendte sine islandske gesandter i slutningen af det 17 . og begyndelsen af det 18 . århundrede for at indsamle alle de middelaldermanuskripter, de kunne finde på islandske gårde, hvorpå de bragte deres bytte ud på deres skibe ved kysten og førte det hjem fra denne perifere $\varnothing$ til konged $\varnothing$ mmets hovedstad. I stedet for at sejle bort med kulturskatte, bragte danske honoratiores nu manuskripterne tilbage til det land, hvor de i sin tid var blevet nedfældet, hvorved de tidligere magtrelationer mellem et moderland og dets oversøiske besiddelse blev vendt om.

For det andet havde manuskripterne, og de historier, de rummer, spillet en afgørende rolle i selve uafhængighedskampen. For de fleste islændinge, og tillige for mange danskere, stod middelalderlitteraturen som selve beviset på den islandske kulturs høje stade. Et folk, som kunne frembringe litterære mesterværker af en sådan karat, fortjente at blive taget alvorligt, skønt forestillingen om islandsk uafhængighed, i alt fald i begyndelsen, havde lydt som en utopisk drøm - om ikke en vits for de fleste danskere.

For det tredje: Da de mødtes på Universitetsbiografens scene, så de danske og islandske kulturministre ud som ligemænd, der repræsenterede to fuldt uafhængige nationalstater. De to nationer havde haft deres uoverensstemmelser i fortiden, men nu var deres mellemværende bragt ud af verden, og tiden var inde til at komme videre.

Endelig repræsenterede manuskripterne for mange islændinge selve indbegrebet af islandsk national kultur. Således definerede disse historiske klenodier for dem, hvad det ville sige at være islandsk, samtidig med at de adskilte islændingene fra andre nationer. Af denne grund måtte de nødvendigvis opbevares på islandsk jord.

\section{Sagalitteraturen som symbol}

Her vil jeg gerne undersøge sidstnævnte påstand en smule nøjere, dvs. se på den rolle, som historiske optegnelser og de kulturelle spor de rummer, spiller i konstruktionen af islandsk nationalidentitet. Sandt at sige har disse optegnelser og den kulturhistorie de stod for, formet de politiske visioner og diskurser i Island i det meste af det 20. århundrede, og symboliserer således den måde, hvorpå islændinge har defineret sig selv som et nationalt fællesskab. Skønt den middelalderlige arv næppe kan betragtes som 'levende virkelighed' i det moderne Island, 
er forestillingen om, at nutiden er formet af en fremadskridende historie med rødder i sagaperioden, således stadig af central betydning for konstruktionen af islandsk nationalidentitet.

Få islændinge spillede så vigtig en rolle i ophøjelsen af de islandske manuskripter og middelalderlitteraturen til at være centrale for identitetsdannelsen i det 20. århundredes Island som den indflydelsesrige professor i middelalderstudier ved Islands Universitet, Sigurdur Nordal.

I 1951 anerkendte den islandske regering Nordals autoritet ved at udnævne ham til landets ambassadør i København med særligt mandat til at tale den islandske sag i diskussionerne om ejerskabet til manuskripterne.

Dette valg skyldtes ikke Nordals diplomatiske erfaring - en sådan havde han ikke - men snarere hans akademiske arbejde i de foregående årtier og hans kontakter til universitetsforskere i den danske hovedstad. Nordal havde længe været fortaler for det synspunkt, at den islandske nationalitet, frem for alt, var grundlagt på Islands litterære kulturarv; ikke blot ejede islændingene sagalitteraturen, hævdede han engang de var også sagalitteraturens ejendom.

Særpræget fra den middelalderlige litteratur kunne spores i hver en afkrog af den islandske kultur, mente han, hvorved islændingene adskilte sig fra alle andre nationer. "Der er ingen tvivl om," skrev han engang, "at kun få andre nationer om overhovedet nogen har levet mere for litteraturen, i litteraturen og af litteraturen end islændingene".

Nordal byggede disse påstande på to fundamentale antagelser. For det første at sagalitteraturen (og dermed altså de manuskripter, som indeholdt de litterære værker) var af islandsk oprindelse og afspejlede miljøet og de sociale vilkår i det middelalderlige Island. For det andet havde den middelalderlige litteraturs arv levet videre i nationen igennem dennes historie, for det meste ubesmittet af udenlandsk 'forurening'. Af denne stod sagalitteraturen som selve symbolet på den islandske kulturs og nationalitets tilblivelse og havde bevaret den i mere eller mindre jomfruelig form igennem århundreders udenlandsk styre.

\section{Islandsk kultur}

Den første del af argumentet var snævert forbundet med den såkaldte 'islandske skole' inden for filologien, som igen på sin side søgte inspiration i den såkaldte Buchprosalehre, eller bogprosateori, der blev introduceret af den tyske 1800-tals-forsker Konrad Maurer og videreudviklet af Nordals forgænger ved Islands Universitet, Björn M. Ólsen.

Kernen i denne teori eller forskningstradition var den påstand, at sagaerne i deres kerne var litterære værker skabt af individuelle, om end sjældent identificerbare forfattere 
snarere end nedskrivninger af fortællinger bevaret og videreført igennem en mundtlig tradition.

På denne måde 'nationaliserede' Nordal og hans kolleger den litteratur, der var bevaret i manuskripterne, for hvis de var litterære værker i den moderne betydning af ordet, var forfatternes nationalitet bestemmende for værkernes nationalitet.

Megen af denne litteratur beskæftigede sig ganske vist med 'fremmede' emner såsom de norske kongers historie eller var af 'fremmede' rødder såsom tyske legender fra den såkaldte eddiske litteratur, men i deres endelige form, hævdede Nordal, udtrykte værkerne de islandske forfatteres skabende geni, og de var således i sandhed islandske.

Af denne grund gav han sit bedst kendte og mest folkekære værk, hvor han beskriver den litterære produktion i det middelalderlige Island og dens kontekst, titlen Íslenzk menning eller 'Islandsk kultur' snarere end Menning Íslendinga, 'islændingenes kultur' - dvs. den litteratur, han analyserede var ikke en islandsk version af germansk eller nordisk kultur, men et udtryk for et unikt og uafhængigt kulturelt fællesskab.

\section{Intellektuel frostboks}

Her kæmpede Nordal og andre fortalere for den islandske skole på to akademiske fronter. På den ene side måtte de forkaste de ideer, der blev fremført af visse norske akademikere, navnlig 1800-talsforskeren Ru- dolf Keyser, som hæudede, at den islandske middelalderlitteratur i sin kerne var norsk.

Keysers argument var, i al fald som Nordal valgte at forstå det, at en stor del af den islandske litteratur reelt havde sin oprindelse i Norge, fordi bosætterne førte legendestoffet med sig, da de rejste fra Norge til deres nye land og bosatte sig her, og at dette således var blevet digtet i deres oprindelsesland og først nedskrevet i det nye hjemland. Ydermere, skrev Nordal, insisterede Keyser på, at Islands indbyggere praktisk taget var nordmænd i de første århundreder af den islandske historie, dvs. i deres litterære produktions glanstid. Disse påstande var efter Nordals opfattelse intet andet end misundelse, hvad der måske kunne være forståeligt, men ikke desto mindre var en fuldkommen vildfarelse.

Faktum var, at meget af det, man vidste om norsk historie frem til 1200-tallet, var skrevet i Island, men ikke i Norge - og dette var, efter Nordals mening "en årsag til undren for vores beslægtede nation og en torn i øjet på den”. Dette førte dem til at betragte Island som en form for 'intellektuel frostboks', skrev Nordal, der bevarede en gammel nordisk kultur i en perifer nordlig øs rolige afsondrethed.

På den anden side brugte de islandske forskere disse argumenter for at støtte de islandske krav om, hvad de definerede som islandske manuskripter i danske biblioteker. 
Deres danske kolleger modsatte sig disse krav med næb og klør med det argument, at det var ren anakronisme at klassificere middelalderlige litterære frembringelser efter moderne, nationalistiske principper. "Det er vist en almindelig forestilling, at håndskrifter på oldnorsk-islandsk er islandske nationalspecialiteter", skrev den danske professor Kåre Grønbech i en artikel oprindeligt publiceret i 1952. "Intet kunne være mere fejlagtigt. De håndskrifter, det her drejer sig om - sagaer, eddaer og dokumenter - udgør, ved siden af arkæologernes udgravede skatte, et fundament for alt, hvad vi ved om vor egen folkestammes oldhistorie, og det fundament er fælles for os alle, danskere, nordmænd, svenskere, færinger og islændinge". Manuskripterne - og middelalderlitteraturen - var derfor ikke mere islandske end danske, skønt de, ubestrideligt, blev skrevet i Island.

Eftersom de skildrede en fællesnordisk, hvis ikke ligefrem germansk, kulturarv, fandtes der ingen legitim grund til, at deres retmæssige ejer, Københavns Universitet, skulle fratages dem, hævdede modstanderne af manuskriptudleveringen.

I sidste ende tabte Grønbech og hans kolleger deres kamp for at bevare alle manuskripterne i Danmark - $\mathrm{i}$ hovedsagen fordi deres ræsonnement ikke blot modsagde de islandske forestillinger om middelalderlitteraturen, men også deres egne borgeres nationalistiske identitet.
Således accepterede flertallet af danske politikere ikke ideen om en fællesnordisk identitet i fortiden eller en fælles fortid for alle nordiske nationer. For dem var indbyggerne i de nordiske lande inddelt $i$ adskilte nationalgrupper med dybe rødder $\mathrm{i}$ deres egen historie.

Og tilbageleveringen af manuskripterne var således en vigtig gestus, der var udtryk for en ny holdning til nationalitet i Danmark. Eller med Poul Engbjergs ord: "Den gamle 'imperialistiske' Kalmarmagt Danmark måtte opgive enhver overordnet rolle i Norden og, som udtryk for den folkelige ligestilling mellem Danmark og Island, overrække islændingene håndskrifterne som gave".

\section{Manuskripter som kulturel markør}

For Sigurdur Nordal var det ikke nok at fastslå sagaernes islandske natur, for i hans øjne havde manuskripterne og middelalderlitteraturen ikke blot været bestemmende for islandsk nationalitet i fortiden, men også opretholdt demarkationslinjen mellem islændinge og andre nationer igennem århundrederne.

I 1924, kort efter sin udnævnelse til professor ved Islands Universitet, udgav han således en antologi over islandsk litteratur, der dækkede perioden 1400-1900. I indledningen, der bærer titlen Kontinuiteten $i$ islandsk litteratur, erklærede han, at hans mål med antologien var at demonstrere, at der bestod et ubrudt 
bånd mellem sagatidens kultur og kulturen i de tidlige 20. århundredes Island.

"En kontinuerlig åndelig kultur af denne art", skrev han, "består, blandt andre ting, i at have styrke til at modstå udenlandske modestrømninger og ekstremisme. Denne styrke har islændingene altid besiddet". Følgelig var det fuldkommen vildledende, når man i værker af udenlandske litteraturforskere ofte kunne se moderne islandsk betegnet som 'neoislandsk' og den moderne islandske litteratur som 'neoislandsk litteratur'.

Disse forskere forstod ikke, hævdede han, at al islandsk kultur - fortidig som nutidig - udgjorde en, sammenhængende blok eller nationalkultur, eftersom der ikke var noget skel, der adskilte middelalderlige litterære mesterværker såsom Njáls Saga eller Eigils Saga fra den romantiske 1800-talsdigter Jónas Hallgrímsson eller Nordals samtidige, den canadisk-islandske emigrantpoet, Stephan G. Stephansson.

Men Nordals hovedbekymring var ikke så meget at korrigere, hvad han så som udenlandske fejlopfattelser af det moderne Islands kultur og samfund, men snarere at varsko sine egne landsmænd om fortidens store rolle i udformningen af deres nutid og, følgelig, deres fremtid.

Således advarende han islændingene om "ikke at bryde den ægte livslinje i nationens historie: den ubrudte kontinuitet i vores sprog og litteratur fra de første bosættelser i Island til nutiden”. Dette var ikke ensbetydende med, anførte han, at islændingene skulle bevare deres fortid i dens oprindelige form - landet skulle ikke gøres til "en national kostald", skrev han. "som ingen udenlandsk lysstråle kan gennembryde, imens folket trygger drøv på og repeterer eddaerne og sagaerne i al evighed".

Snarere skulle fortiden være del af og med til at skabe en moderne kultur, der nok værnede om sine traditioner, men også var åben for nye ideer, så længe disse kunne tilpasses dens historisk overleverede kulturmønstre.

\section{Fra kulturel patriotisme...}

Nordals teorier om produktion og reproduktion af den islandske nationalidentitet var grundlæggende kun en variation over gammelkendte temaer i islandsk politisk og kulturel diskurs. Såedes havde det islandske sprog og Islands middelalderlige kultur i århundreder haft en næsten mytisk status som Skandinaviens 'oprindelige sprog' eller det nordiske Ursprache:

"Hvor man kommer paa Landet", skrev fx den islandske 1700-tals naturforsker og digter Eggert Ólafsson, "forstaaer den gemeene mand alle de gamle Sagar (sic) Ord fra Ord". Dette var et meget positivt tegn, kommenterede han, fordi det beviste, at "dette i Europa ældste levende Sprog befindes virkelig i saa- 
dan en Tilstand, kunde det endnu holdes ved Lige, og dets Undergang forebygges". For ham var bevarelsen af det islandske sprog vigtigt, fordi det opretholdt forbindelsen mellem nutiden og Islands glorværdige fortid, og på samme tid var en definerende faktor i hans samtids islandske 'nationalidentitet'. At bevare et sprog var således det samme som at bevare nationen. Sproget var et tegn på, hvem man var, hævdede Ólafsson, hvorfor "de største Helte og viiseste Regenter (hvoriblandt kan nævnes i de ældre tider Carl den Store, og i de nyere, Ludvig den 14de) have ladet dem, iblandt andre vigtige Ting, deres Sprogs Bevaring være angelegen".

Eggert Ólafssons protonationalistiske argument var således ikke hans påfund, eftersom vi kan spore det så langt tilbage som til begyndelsen af 1600-tallets Island. I sin apologi for sit moderland betitlet Crymogea sivi rerum Islandicarum, offentliggjort i Hamburg i 1609, påpeger den islandske humanistiske forsker og lutheranske præst Arngrímur Jónsson, at kun islændingene blandt de nordiske folkeslag talte middelalderens sprog, hvorfor han opfordrede dem indtrængende til at bevare det rent og ubesmittet af udenlandsk indflydelse. Hvorfor islændinge skulle gøre dette, fremgår ikke klart af Jónssons tekst, som for øvrigt er skrevet på latin, men læseren må formode, at han tænkte sig, at den sproglige forbindelse til sagaernes tid kunne berige hans samtidiges tilværelse. Jónsson havde så afgjort skrevet Crymogaa for at opmuntre sine landsmænd til at reflektere over "hvem vi er, og hvem vi har været".

Ingen af disse to kommentatorer drog dog specifikke politiske konklusioner fra deres bemærkninger om det islandske sprog. Det var en kilde til stolthed for dem og demonstrerede, at folket på denne fattige og fjerne $\varnothing$ havde bevaret deres kulturarv til trods for deres påfaldende forarmelse i senere århundreder. At tale et ædelt sprog gav for dem ikke et folk nogen særlige politiske rettigheder eller målsætninger, eftersom begge disse forfattere var udmærket tilfredse med det danske styre i Island.

\section{... til politisk nationalisme}

I 1800-tallet fik den islandske sproglige stolthed en interessant politisk drejning, idet forestillingen om det oprindelige sprog blev brugt til at legitimere islandske krav om autonomi fra Danmark og senere krav om suverænitet og fuld uafhængighed.

Et af de tidligste tegn på denne nye følelse dukkede op i det islandske litterære og politiske tidsskrift, Fjölnir, hvis første nummer udkom i København i 1835. I indledningsartiklen til første nummer sporede den lutheranske pastor og en af journalens fire oprindelige redaktører, Tómas Sæmundsson, den islandske nations påståede kraftesløshed tilbage til dens unaturlige rege- 
ring. For at beskytte folkets friheder og rettigheder, hævdede han, måtte nationer vælge nogle få mænd iblandt dem til at føre den nationale vilje ud i livet. "Men undertiden har disse mænd misforstået nationen på en sådan måde, at de ser sig selv som konger af Guds nåde, men alle andre som slaver".

Det er imidlertid ikke udelukkende suveræne, som undertrykker deres undersåtter. "Undertiden kommer hele nationer på afveje og tror sig berettigede til på bedragerisk vis at påtvinge sig herredømme over andre nationer og berøve disse deres frihed... Denne form for undertrykkelse, om den udgår fra de mange eller fra de få, udrydder den nationale ånd, og dette er den værste ulykke, der kan overgå nogen stat."

Ydermere, anførte Sæmundsson, bliver nationer, der er styret af udlændinge, uanset om deres herskeres love er vise og retfærdige, apatiske og svage. Dette udsagn kan kun forstås som en slet skjult afstandtagen fra det danske styre i Island, om ikke for dets undertrykkende natur så i al fald for de lammende effekter, det angiveligt havde på den islandske nationalånd.

"Ingen nation eksisterer, før den taler sit eget klart adskilte sprog", skrev Sæmundsson "og hvis sproget dør, dør nationen med det eller bliver forvandlet til en anden slags nation". Dette generelle princip var af særlig betydning for islændingene, anførte Sæmundsson, fordi de "taler et af den vestlige halvkugles ældste sprog, hvilket tilsammen med den islandske litteratur og historie udgør grundlaget for deres nationale ære”. Af denne grund havde islændingene pligt til at holde deres tale fri af fremmede ord og udvikle "denne uvurderlige skat, den fælles ejendom for alle, som kan kaldes islændinge".

Sæmundssons tankegang finder åbenlys genklang hos ikke blot hans islandske forfædre såsom Arngrímur Jónsson og Egger Óiafsson, men også i den tyske filosof Johan Gottfried Herders skrifter. I Herders filosofi er sproget på samme tid nøglen til menneskets selvforståelse og det medium, hvorigennem en person kommunikerer med en anden. Folks følelser har sine rødder i deres modersmål, hævder Herder - dvs. i det sprog, de lærer i deres barndoms- og ungdomsår. De første ord, børn hører fra deres forældres mund, former deres sind og sjæle, forklarer han i sin Abhandlung über den Usprung der Sprache (1772).

Et folk er derfor nødt til at bevare sit modersmål, thi intet andet sprog kan give fuld adgang til menneskesindets dybder.

\section{Kosmopolitisk perspektiv}

Vi kan betragte Herders ideer som en reaktion på Oplysningstidens universalistiske tilbøjeligheder. For ham besad ethvert kulturfællesskab, eller Volk, klart adskilte traditioner, der havde udviklet sig igennem kon- 
tinuerlige historiske processer. Således afspejlede den lokale natur den pågældende menneskegruppes naturlige miljø. Det samme princip havde gyldighed for nationer som for individer, fordi nationalsprog de nationale modersmål - udtrykte nationers sjæl og deres 'autentiske natur'. Sprog overfører nationers erfaringer, tænkte Herder sig, deres historie, deres kamp med det naturgivne miljø og for deres overlevelse; følgelig arver nye generationer deres forfædres kulturelle præstationer i kraft af deres fælles sprog.

Trods disse nationalistiske og partikularistiske undertoner var Herders tænkning bemærkelsesværdig kosmopolitisk i sin natur. For ham var menneskeracens mangfoldighed af største væsentlighed, og intet sprog eller nogen kultur var andre sprog og kulturer overlegne.

Med andre ord var nationernes system en guddommelig gave, hvor hvert sprog udgjorde et af stemmerne i et universelt kor.

Dette kosmopolitiske perspektiv har aldrig været centralt i den islandske lingvistiske og historiske diskurs. Snarere end at betragte deres sprog som del af et komplekst mønster af ligefuldt vigtige idiomer, har islandske nationalister hyppigt anset det for unikt og på en eller anden måde ædlere end de fleste andre sprog på grund af dets stærke lighed med sproget fra sagaernes og Islands 'guldalder'.

Islandsk er Europas ældste sprog, anførte Tómas Sæmundsson i sin indledning til tidsskriftet Fjölnir, og er bevaret praktisk taget uforandret fra den islandske histories glorværdigste dage, og af denne grund var det exceptionelt værdifuldt som nationalsprog.

Ydermere havde islændingene formået at overleve i kraft af deres kulturelle vedholdenhed, eller det var i al fald, hvad utallige islandske politikere hævdede i deres taler til nationen. "Her i norden", erklærede Ásgeir Ásgeirssonj, daværende formand for det islandske parlament og den anden præsident for den islandske republik, på Thingvellir i 1930, "er en af den moderne kulturs stærkeste islæt blevet bevaret: den gamle germanske kultur. Det er en hellig tråd i vores historie, den ingrediens, som har værnet nationen imod fortabelse, da fremmedherredømmes klør, sygdom og hungersnød næsten havde ødelagt det”.

Islands nationalisme søger derfor inspiration i den europæiske lingvistiske nationalisme, som Johann Gottlieb Fichte udtrykker klarest i sin $R e^{-}$ den an die deutsche Nation, en række af foredrag henvendt til Berlins borgere under den franske besættelses vanskelige vinter i 1807-08.

For ham var sproget den vigtigste del af menneskets kultur, fordi - for at citere ham - "indem weit mehr die Menschen von der Sprache gebildet werden, denn die Sprache von Menschen". Det var derfor ikke tilstrækkeligt for nationer at tale de- 
res nationale sprog for at få adgang til deres sande ånd og sjæl: Deres sprog måtte nedstamme direkte fra de sprog, som gruppens oprindelige forfædre talte. Set i dette lys havde det tyske sprog en særstatus i Euro$\mathrm{pa}$, påstod han, fordi tyskerne $\mathrm{i}$ modsætning til de fleste andre europæere ikke havde antaget latin i de århundreder, der fulgte efter Romerrigets sammenbrud. Det var de forgangne tiders tyskeres uafladelige modstand der ifølge Fichte reddede den tyske nation fra tilintetgørelse.

Det er svært at finde eksplicitte spor af Herders og Fichtes indflydelse på islandske intellektuelle og politikere, men myten om den ubrudte kontinuitet havde fra et funktionelt synspunkt en altafgørende værdi for Sigurdur Nordals generation og hans forgængere, fordi den viste sig som det mest effektive argument for kravet om en selvstændig islandsk stat.

"Den islandske nation er den eneste germanske nation, der har bevaret det gamle sprog, som blev brugt $i$ alle nordiske lande for 900-1.000 år siden”, hævdede islandske medlemmer af den parlamentariske komité, som havde forhandlet om oprettelsen af en suveræn stat i Island i 1918. "Det er vores faste formening, at disse omstændigheder - et klart adskilt sprog og en klart adskilt kultur - giver os en historisk og naturlig ret til fuld uafhængighed".

Hvad der gjorde dette krav til et så potent våben i kampen for uaf- hængighed, var det faktum, at deres modstander, den danske regering, troede lige så glødende på sin legitimitet, som islændingene gjorde på deres. N. F. S. Grundtvig, som mere end nogen anden formulerede den danske nationalidentitet i første halvdel af 1800-tallet, er et oplagt eksempel:

"Nedtrykt over Storbritanniens sejr over Danmark i 1807-14-krigen", skriver historikeren Uffe Østergård, "oversatte Grundtvig islandsk middelalderlitteratur til moderne dansk i sin søgen efter den oprindelige nordiske eller danske sjæl”, eller efter "danskhedens sande, men tabte kerne". Formodningen var således, at islandsk sprog og kultur for danskerne åbnede en adgang til dem selv i deres egen autentiske natur, dvs. at den herskende magt var henvist til at måtte søge sin 'indre sjæl' i sin stats perifere kultur.

\section{Den nationalistiske arv}

Understregningen af kontinuitet og enhed mellem fortid og nutid angav ikke blot referencerammen for den nationale identitet for islændinge $\mathrm{i}$ det 19. og 20. århundrede, den dannede også den grundlæggende præmis for islandsk nationalisme i det politiske liv.

Trods heftige konfrontationer imellem partierne på venstre- og højrefløjen i 1930'erne og 40'erne herskede der således fuld enighed imellem de islandske politikere, når det gjaldt om at definere den island- 
ske nationalstats grundlæggelsesmyter. For dem alle var sagaperioden eller 10-1300 tallets unionstid den glorværdige begyndelse til den islandske historie, ikke blot på grund af epokens kulturelle kreativitet, men også fordi nationen dengang havde været uafhængig af fremmed styre. Den nationale friheds ånd blev født i denne guldalder, hævdede nationalisterne, og den havde levet videre $\mathrm{i}$ islændingenes hjerter igennem århundreder, indtil den for alvor blev genoplivet med kampen for uafhængighed i det 19. århundrede.

Parallellerne mellem denne politiske tankegang og de kulturelle argumenter, jeg skitserede før, er umiskendelige. Således var det i politik en iboende længsel efter frihed og national følelse, der knyttede nutidens islændinge sammen med deres forfædre, mens sproget og de litterære traditioner i kulturen blev set som det bånd, der forenede moderniteten med den historiske arv.

Og på samme måde, som de intellektuelle søgte at bevare de sproglige og kulturelle traditioner, så politikerne det som deres mission at holde opmærksomheden om deres nationale strid i live, fordi det hellige bånd til fortiden ellers ville blive brudt. "Den generation, der nu vokser op," skrev formanden for det prosovjetiske Socialistiske Enhedsparti, Einar Olgeirsson, i 1944, "har selv ingen erfaring og kun lidet kendskab til den nationale kamp for uafhængighed. Det forekommer sandsynligt, at denne tråd tilbage til vores frihedskamp vil blive brudt i denne generation, medmindre vi gør enhver tænkelig indsats for at forstærke den, for at holde kampens tradition i live og for at gøre forgangne generationers anstrengelser og stræben efter frihed til en vigtig del af de unge generationers liv og bevidsthed".

\section{Republikkens genopståen}

Trods disse bekymringer satte Olgeirsson sin lid til republikken, der blev grundlagt den 17 . juni 1944, idet han - i lighed med sine politiske kolleger - generelt så det som både en opfyldelse af et gammelt løfte og et glorværdigt eksempel på, hvad den islandske nationalånd kunne udrette.

I en vis forstand var det en klar manifestation af, hvordan historien og nutiden sammensmeltede, fordi nationen nu omsider var fri og forenet. "Den islandske republik er genopstået", erklærede Ólafur Thors, leder af centrumhøjrepartiet Det Uafhængige Parti den 18. juni 1944, da Reykjaviks indbyggere fejrede grundlæggelsen af republikken dagen før.

Den nye institution var, fundamentalt set, ikke en moderne demokratisk samfundsdannelse eller en nøje efterligning af et fælleseuropæisk paradigme, men snarere en genskabelse af den middelalderlige union. Da den islandske præsident blev indsvoret til sit embede i Thing- 
vellir - et sted, der ofte ses som det symbolske centrum for islandsk nationalisme - svor politikerne deres enhed med de høvdinge, som havde forsamlet sig på de selv samme marker syv århundreder tidligere.

Opmærksomheden på denne enhed blev højnet igennem den enstemmige støtte, som republikken havde i nationen. Som Kristinn E. Andrésson, dengang en af de intellektuelle ledere af Det Socialistiske Enhedsparti, udtrykte det, var den folkeafstemning, der gik forud for grundlæggelsen af republikken i 1944 "et ypperligt vidnesbyrd om islandsk årvågenhed”, eftersom “der ikke var nogen islænding, hverken ung eller gammel, hverken bybo eller landbo, som ikke forstod, at folkeafstemningen angik Islands ære, frihed og fremtid... Hvor herligt var det ikke at opleve den enstemmighed, der kom til udtryk i folkeafstemningen... Folk af alle partier samarbejdede, alle med den samme entusiasme. Al partistrid var glemt. Nationen havde én interesse, én vilje, én sjæl. Derfor var denne sejr fuldkommen".

For en moderne iagttager må det være temmelig indlysende, at denne dobbelte enhed mellem fortid og nutid byggede på politisk fiktion snarere end realiteter. Således har den moderne republik ikke meget til fælles med det islandske middelaldersamfund, og ej heller varede den politiske harmoni fra 1944 da ret længe. Så snart diskussionerne om den Kolde Krig tog til i årene efter Anden Verdenskrig, fór de modstridende fløje i harnisk og beskyldte hinanden for at forråde den hellige pagt fra 1944.

Dette betyder imidlertid ikke, at det højtidelige løfte om enhed simpelt hen var tom retorik eller en rituel øvelse blottet for al mening. Faktisk tjente den som en af de stærkeste motiverende idealer i islandsk politik igennem republikkens historie. Dette er hovedgrunden, kunne man hævde, til, at de islandske politikere har været meget mindre modtagelige over for Den Europæiske Unions idealer end deres kolleger i de andre nordiske lande - eller for at sige det på en anden måde, til, hvorfor det har været umuligt for dem åbent at ansøge om medlemskab af unionen, skønt de på samme tid har gjort Island til en de factomedlemsstat af unionen ved at acceptere Det Europæiske Økonomiske Samarbejdsområde (EØS) og Schengen-aftalen.

\section{Fra enhed til mangfoldighed}

I dag ligner Island de fleste af sine nabolande på den vestlige halvkugle. Det er velstående, urbaniseret, demokratisk, industrialiseret og i de senere år er den neoliberale kapitalisme gradvis blevet den dominerende politiske ideologi.

Og som i andre samfund i en lignende situation har den islandske modernitet udviklet sig igennem et revolutionært brud med fortiden - 
dvs. at samtidig med at vor tids Island minder meget om sine nabosamfund, er det meget anderledes end fortidens islandske samfund. Dette er et af de fascinerende paradokser ved islandsk politisk og intellektuel historie - at den islandske lingvistiske og kulturelle nationalisme dukkede op på samme tid, som forskellene i forhold til verden udenfor gradvis var ved at forsvinde, og kløften mellem den islandske fortid og nutid blev stadig dybere.

Spændingen mellem ønsket om enhed mellem fortiden og nutiden og de konstante forandringers realitet har været et af de vigtigste temaer i Islands nyere kulturelle og politiske historie. Således frygtede intellektuelle fra det tidlige 20. århundrede, at den påståede sproglige og kulturelle enhed ville blive brudt, når landets geografiske isolation gradvis bragtes til ophør, hvorved den islandske nationalkulturs særpræg ville blive undergravet.

"Nye temaer kommer med nye horisonter", skrev Sigurdur Nordal i 1924, "og vore digtere kan få vanskeligt ved at indpasse dem inden for den gamle digterkunst snævre grænser”. Dette vil formentlig føre til eksperimenter og innovationer, hvor forfatterne opgiver og forbigår den islandske digtnings traditionelle stilarter, forudså han, og dette voldte ham dyb fortrydelse, fordi "sprogets renhed og digtningens klange frem for noget har været de afslørende tegn på vores nationale kulturs op- gangs- og nedgangstider”. Islandske digtere efter Anden Verdenskrig gjorde selvfølgelig nøjagtig, hvad Nordal frygtede. Dvs. de brød bevidst med den islandske digterkunsts så ærbødigt respekterede traditioner. Efter deres opfattelse kunne 'atomalderens' bekymringer og følelsesliv ikke længere udtrykkes i et sprog og litterære former, der stammede fra 1200-tallet, og derfor måtte de islandske kulturmønstre revolutioneres, hvis de fortsat skulle have kunstnerisk betydning.

Dvs. at på samme tid, som manuskripterne blev krævet tilbage, gled de i baggrunden i den folkelige bevidsthed. Skønt moderne udgaver af sagaerne stadig er fast inventar i de fleste islandske hjem, læses de knapt nok mere bortset fra af akademiske eksperter og skolebørn, der har dem som obligatorisk læsning på deres pensum.

Skønt det akademiske miljø i Island i vidt omfang har accepteret, hvad der kunne kaldes afslutningen på uafhængighedskampen og ser islandsk kultur og historie som integreret del af den europæiske udvikling, har dette dog ikke haft megen indflydelse på landets politiske diskurs.

Islandsk politik kom til verden i det sene 19. århundredes og tidlige 20. århundredes nationalistiske eufori, og den periodes idealer og holdninger bruges stadig som grundlæggende reference for alle politiske debatter. En grund til dette er 
den faste tro på korrelationen imellem national enhed, uafhængighed og økonomisk fremskridt.

Dette var kernebudskabet, da Islands første præsident, Sveinn Björnsson, talte til sit folk i Reykjavik den 18. juni 1944: "Dette land har været beboet af en forenet nation i over et årtusind uden opblanding med andre folkeslag. Nationen taler og skriver sit eget sprog, så rent det er, måske den eneste nation i verden, der ikke er delt op imellem dialektale grupper. Vi har vores egen historie, hvor perioder af lys og skygge veksler. - Denne historie beviser, at vi har blomstret mest, når frihedens lys er skinnet, men klaret os langt ringere, når et fremmed herredømmes skygge har domineret".

Hans budskab var derfor, at en uafhængig nation, som var forenet sprogligt og som talte et 'rent' sprog, med sikkerhed ville trives og få økonomisk fremgang, hvorimod afhængighed og mangfoldighed uvægerligt ville føre nationen ud i katastrofer.

Politikerne gennemspiller stadig dette tema ved højtidelige lejligheder og sætter lighedstegn mellem national frihed og økonomiske fremskridt. Det må imidlertid bemærkes, at trods den strengt nationalistiske tone, har intet fremmedhadsk parti nogensinde vundet fodfæste $\mathrm{i}$ islandsk politik.

Et godt eksempel på dette er indvandringsspørgsmålet. I løbet af det seneste årti er der sket en stærk til- strømning af indvandrere til Island, hvorved antallet af udenlandsk fødte indbyggere har nået et niveau, der er sammenligneligt med andre europæiske staters. Midt i 1990'erne var således omkring 4 procent af Islands indbyggere født i udlandet, mens denne andel i 2005 er steget til over 8 procent.

Denne voksende minoritet kan få retslig anerkendelse som islændinge, idet de kan opnå islandsk statsborgerskab efter fem års ophold i landet, men eftersom de ikke sætter de middelalderlige manuskripter i Árni Magnússon Instituttet i centrum af deres identitet, er det et spørgsmål, om de nogensinde vil blive betragtet som virkelige islændinge. Hvordan denne diskrepans imellem islandsk nationalidentitet og national realitet vil blive udbedret er stadig et åbent spørgsmål.

\section{Vil båndet blive brudt?}

"Det er interessant at overveje spørgsmålet om, hvordan elementer i vores kultur og historie har spillet en rolle i vores oversøiske eventyr", sagde Islands præsident, Ólafur Ragnar Grímson, i et nyligt foredrag ved et møde for islandske historikere. Emnet for hans tale var, hvad islændingene kalder útras (udfald) eller den aktuelle måde, hvorpå det islandske erhvervsliv søger at øge sin indtjening på udenlandske investeringsmarkeder.

Indtil slutningen af det 20. århundrede forblev den islandske økono- 
mi bemærkelsesværdigt lukket, eftersom udenlandske investeringer $\mathrm{i}$ Island var særdeles uvelkomne (og således stadig er forbudt i økonomiske nøglesektorer såsom fiskeri), samtidig med at islandske investeringer uden for landet selv var uhyre sjældne.

Denne forskanselsesmentalitet forduftede hurtigt i 1990'erne, og nu kigger de fleste islandske investorer mod de europæiske marker som operationsfelt.

For Grímsson er dette et sikkert tegn på, hvordan fortiden har formet den islandske nutid eller på, "hvordan de egenskaber, vi har arvet fra vore forfædre muligvis kan give os en fordel på den internationale arena, og hvordan opfattelser og vaner, som i århundreder har sat deres præg på vores samfund, har vist sig som værdifulde aktiver for vore dages succesmagere på den internationale scene", som han udtrykker det.

Hvad præsidenten gik let hen over i denne tale er imidlertid det faktum, at det islandske samfund i århundreder var stærkt reaktionært og modsatte sig alle forandringer. Således er hans påstand om, "at vore fremstød på de oversøiske markeder er dybt rodfæestet i vores historie" i bedste fald tvivlsomt, hvis ikke en fuldkommen fejlagtig fremstilling af den islandske fortid.

Men uanset hvad, er det et afslørende tegn på, hvordan islandske politikere fortsætter med at læse den islandske historie igennem en nationalistisk optik, hvor nutiden uanset hvor forskellig den er fra fortiden - ses som den naturlige fuldbyrdelse af den islandske historie. Hvor der er et åbenlyst brud, ser de kontinuitet, og hvor der er konvergens, ser de modstrid.

Hvor det islandske erhvervsliv således bliver stadig mere internationalt i sin orientering og bryder uopretteligt med det islandske bondesamfunds normer fra tidligere århundreder (sparsommelighed, forsigtighed, forudseenhed osv.), ser de islandske nationalister vore erhvervsfolk som den moderne tids vikinger.

Historiske argumenter bliver følgelig stadig brugt i konstruktionen af den islandske nationalidentitet, men de søges i de historiske myter snarere end i de akademiske historikeres kritiske diskurs.

Gudmundur Hálfdanarson er professor $i$ historie ved Islands Universitet. 